\title{
A STATISTICAL MODEL FOR ESTIMATION OF ICHTHYOFAUNA QUALITY BASED ON WATER PARAMETERS IN OITUZ BAZIN
}

\author{
Carmen POPESCU *, Dorel URECHE **, Camelia URECHE ** and Elena NECHITA * \\ * "Vasile Alecsandri” University of Bacău, Department of Mathematics, Informatics and Educational \\ Sciences, Calea Mărăşeşti 157, Bacău, Romania, RO-600115, cmuraru@ub.ro, enechita@ub.ro \\ ** "Vasile Alecsandri" University of Bacău, Department of Biology and Environmental Protection, \\ Calea Mărăşeşti 157, Bacău, Romania, RO-600115, dureche@ub.ro, urechecami@yahoo.com
}

KEYWORDS: Romanian Carpathians, lotic system, ichtyofauna, estimation model.

\section{ABSTRACT}

Fish represents an important food source for people worldwide. Moreover, although considered a very old occupation, fishing continues to provide jobs, especially for the people living in the coastal countries. The quality of surface waters affects the quality of fish as a food source. For this reason, the present study aims to assess the quality of the ichthyofauna in the Oituz River and some of its tributaries using several parameters that have been computed based on the biometric data of the biological material gathered during 2004-2008, in correlation with the water $\mathrm{pH}$ and water temperature. The present paper also highlights some observations regarding the changes of the analyzed ecosystems, as well as some recommendations regarding the fish consumption in the studied basin, considered as a food source for humans.

RÉSUMÉ: Modèle statistique basée sur les paramètres de l'eau, pour estimer la qualité de l'ichtyofaune, dans le bassin de la rivière Oituz.

Le poisson est une source importante de nourriture pour les humains. En outre, bien qu'il s'agit d'une très vieille activité, la pêche continue à fournir des emplois, en particulier pour la population des pays riverains. La qualité de l'eau de surface détermine aussi la qualité du poisson comme source de nourriture. Pour cette raison, cette étude envisage l'estimation de la qualité d'ihtyofaune dans la rivière Oituz et quelques affluents, faisant usage des paramètres qui ont été calculées sur la base de données biométriques du matériel biologique pris dans la période de 2004-2008, en corrélation avec le pH et la température de l'eau. Ce travail fait aussi des observations sur les changements dans les écosystèmes analysées, ainsi que des recommandations sur la consommation de poisson du bassin étudié, aperçu comme nourriture pour l'homme.

REZUMAT: Model statistic bazat pe parametrii apei, pentru estimarea stării ihtiofaunei din bazinul râului Oituz.

Peștele reprezintă o importantă sursă de hrană pentru om. În plus, pescuitul, deși este o îndeletnicire foarte veche, continuă să furnizeze locuri de muncă, mai ales pentru populația din țările riverane. Calitatea apelor de suprafață determină și calitatea peștelui ca sursă de hrană. De aceea, prezentul studiu vizează estimarea calității ihtiofaunei din râul Oituz și câțiva afluenți, utilizând parametri care au fost calculați pe baza datelor biometrice ale materialului biologic capturat în perioada 2004-2008, în corelație cu pH-ul și temperatura apei. Lucrarea evidențiază și observații privind modificări ale ecosistemelor analizate, precum și recomandări privind consumul peștelui din bazinul analizat ca hrană pentru om. 


\section{INTRODUCTION}

Certain environmental problems are embedded in social-ecological systems (Schlüter et al., 2012), which are systems with a high degree of complexity. The complexity derives from multiple interactions (both on spatial and on temporal scales) between the social communities and the ecological systems that are supporting them, as well as from profound uncertainties (Berkes, 2007; Fulton et al., 2011). Modelling is a traditional tool in natural resource management to study such complex systems (Bousquet and Le Page, 2004; Carpenter et al., 1999; Schmolke et al., 2010), benefiting of results from different areas such as numerical optimization, visualisation, graph theory, agent-based and network approaches, and statistics.

Waters and fisheries count among the systems which have to be studied in order to improve the understanding of the processes and factors that could lead to sustainable outcomes. There are numerous numerical models for fish life: transit of fish eggs, larvae, and nursery areas (Hilborn and Walters, 1987). The best suited mathematical models are based on the direct extraction of information from existing data sets (i.e., empirical approaches), but the modelling tools depend on the objectives of the modelling (North, 2009). The model formulations are situation-specific (Ibarra et al., 2005; Milner-Gulland, 2011).

Since 1900, fish populations have been used as environmental indicators. Researchers have proved (Simon, 1999) that the relative health and condition of an aquatic community is a sensitive measure of the site-specific condition. On the other side, environmental factors (such as water temperature, salinity, depth and mud percentages, metals concentration, etc.) are frequently selected as predictor variables of the models. In line with this course, the present paper offers an estimation model for the quality of waters of the Romanian river Trotuş, based on the data gathered for two years related to the fish populating the river.

Trotus is an important river of the largest hydrographic basin of Romania, in Siret Basin. Its origin is in the Trotuş Mountains, at 1,380 m altitude. Although it is a river with medium length $(162 \mathrm{~km})$, Trotuş River crosses an extremely varied landscape, with a difference level of (from spring to inflow) more than $1,000 \mathrm{~m}$. Variations of the air temperature in Trotuş Basin display alpine climate conditions on the highest peaks, while being mild or with thermal inversions in depressions and valleys. Near the city Oneşti, Trotuş is collected by Oituz River. (Ujváry, 1972; ***, 1992)

As far as the pollution in the Oituz River basin area is concerned, we mention some aspects which can influence the quality of the ichtyofauna. In this area, there is a sawmill at Oituzul Ardelenesc and two sawmills at the exit from Oituz, at Bâtca point.

The forest exploitations in Brețcu and Oituz Forest Districts and in Mereni and Oituz Private Forest Districts cause a series of negative phenomena on the riverbed. During 2008, in the settlements of Oituz River basin there were about 100 circular saws producing sawdust which can reach the riverbed in some areas, thus altering the habitat conditions. Another consequence of deforestation is the increase of water temperature due to the lack of shading which limits the survival of the salmonids and the benthic invertebrates in the river water.

Other sources of pollution are the sump salvages of Halos and Ferastrău areas, as well as the fecal-domestic pollution from the coastal villages. There is no industrial pollution there.

Fish - as poikilothermic species - do not need energy for the body temperature adjustment. The body temperature of the fish is 0.5-1 degrees higher or lower than the temperature of the water in which they live. The intensity of their metabolism is closely related to the fish size, water temperature and water $\mathrm{pH}$ (among others) so our analysis is based on this correlation. For example, trout grows well at temperatures of 12-18 degrees, while at higher temperatures their metabolic rate decreases. Generally, the climate changes have a major influence on fish, both regarding the survival of the individuals and of species. (Moyle, 2002) 
The water temperature is an important factor to consider, due to its influence on every other of its quality parameters: conductivity, salinity, oxidation reduction potential, $\mathrm{pH}, \mathrm{CO}_{2}$, compound toxicity, dissolved oxygen (Moyle, 2002). The temperature can alter the physical and chemical properties of water. In this regard, water temperature should be accounted for when determining the metabolic rates and photosynthesis production. Temperature fluctuations can also affect the behaviour choices of the aquatic organisms. (Wetzel, 2001)

The $\mathrm{pH}$ of pure water varies with temperature. Pure water only has a $\mathrm{pH}$ of 7.0 at 25 degrees Celsius. The $\mathrm{pH}$ value is influenced by the dissolved organic matter, the melting snow and rainfall, and the sewage discharges. For example, the optimum $\mathrm{pH}$ value for the salmonids must range between 7 (neutral) and 8 (alkaline), while the values below 5.5 or above 8.5 are unsuitable for their development. (Baldisserotto, 2011)

\section{MATERIAL AND METHODS}

Our statistical modelling is based on the regression technique which illustrates the correlation between the dependent variables fish weight and fish length with the temperature and $\mathrm{pH}$ of water as predictors. Moreover, the analysis compares the statistical results from two different periods of time, 2004 and 2008, in order to observe if important changes came up. In social and natural sciences, multiple regression procedures are widely used in research, as these allow researchers to answer questions that consider the role(s) that multiple independent variables play in accounting for variance in a single dependent variable. Our implementation of regression model uses functions from Matlab toolboxes.

A rigorous substantiation of the existence of a correlation and, afterwards, the design of the model which describes the correlation (the regression model) is based on the calculation and interpretation of several statistical indicators. The following stages have been run through: verification of the existence of a correlation, analysis of the empirical regression curve, determination of the mathematical equation of the model and of its parameters, and use of the model for prognosis.

Our statistical analysis was based on data from Oituz River, on certain species that were found in most of the collection points: Phoxinus phoxinus ( $\mathrm{L}=8-14 \mathrm{~cm}, \mathrm{G}=10-14 \mathrm{~g}$ ), Squalius cephalus $(\mathrm{L}=25-30 \mathrm{~cm}, \mathrm{G}=0.3-1.5 \mathrm{~kg})$, Salmo trutta fario $(\mathrm{L}=25-30 \mathrm{~cm}, \mathrm{G}=0.8$ $1.6 \mathrm{~kg}$ ) and Barbus meridionalis ( $\mathrm{L}=20 \mathrm{~cm}, \mathrm{G}=300-400 \mathrm{~g})$.

The figures between parentheses indicate the average length and weight for the individuals of that species. The metabolism intensity depends more on the size of the fish than on the age and it is inversely proportional to the size of the fish.

The data were collected in two years, in the sampling sites indicated in figure 1 for the year 2004 and in figure 2 for the year 2008. The biological material was sampled through electrofishing, using the "catch and release" method. Every collection point is associated with one value for weight and one for length, representing the average values of these characteristics for the individuals captured in that location. We also mention that the measure units for the two variables, weight and length, were grams and centimetres, respectively.

The above mentioned species differ in their capacity to adapt to the climate and environmental conditions. Salmo trutta fario prefers low temperatures: 12-19 degrees Celsius (Raleigh et al., 1986), and even less in the reproductive period, around 6-8 degrees Celsius (Bănărescu, 1964). There are studies showing that, if possible, the trout avoids temperatures above 13 degrees Celsius (Moyle, 2002), and tolerates a $\mathrm{pH}$ between five and 9.5, the optimum values being 6.8-7.8 (Raleigh et al., 1986). 


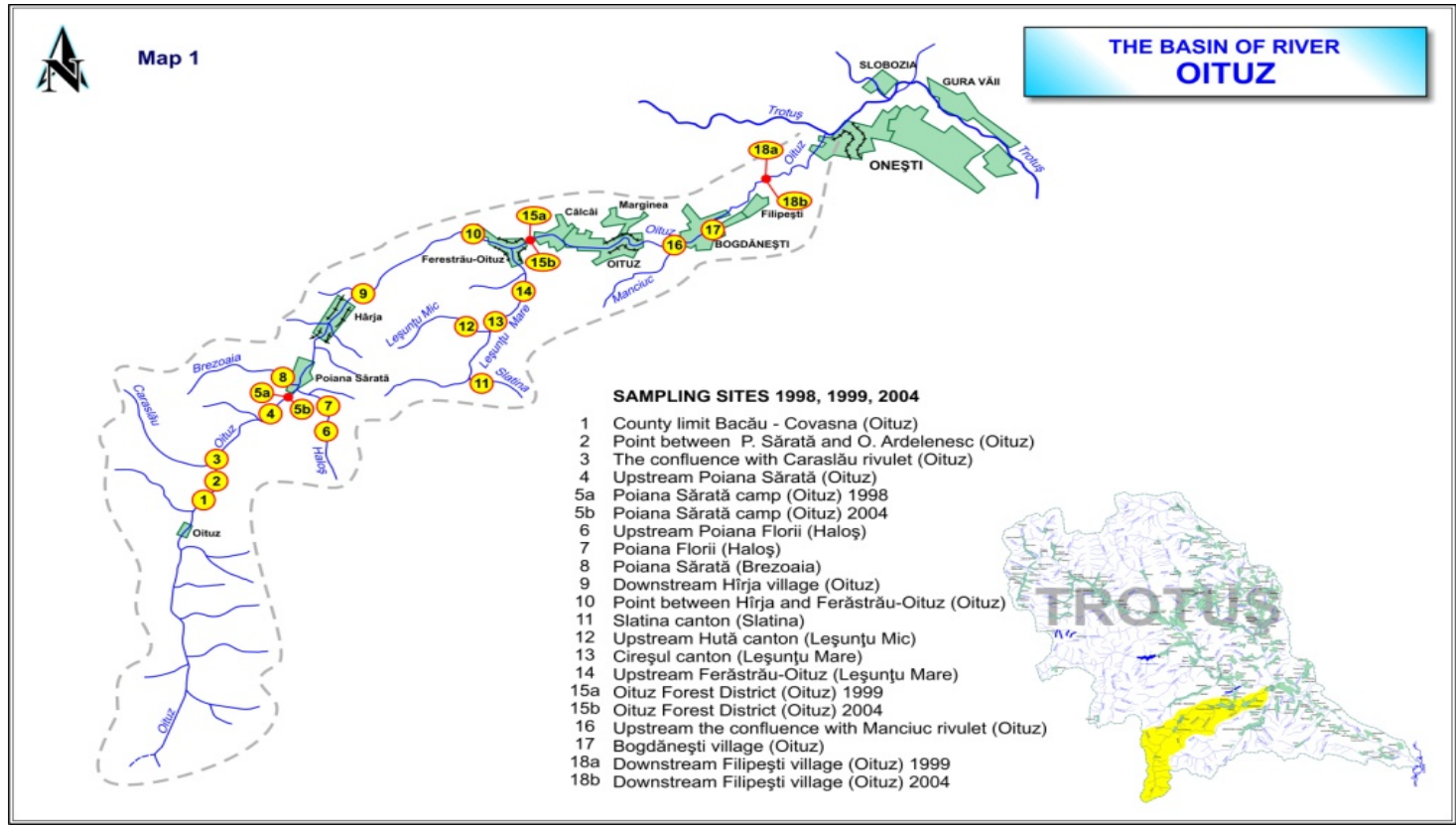

Figure 1: Sampling sites used in 2004 in the basin of river Oituz.

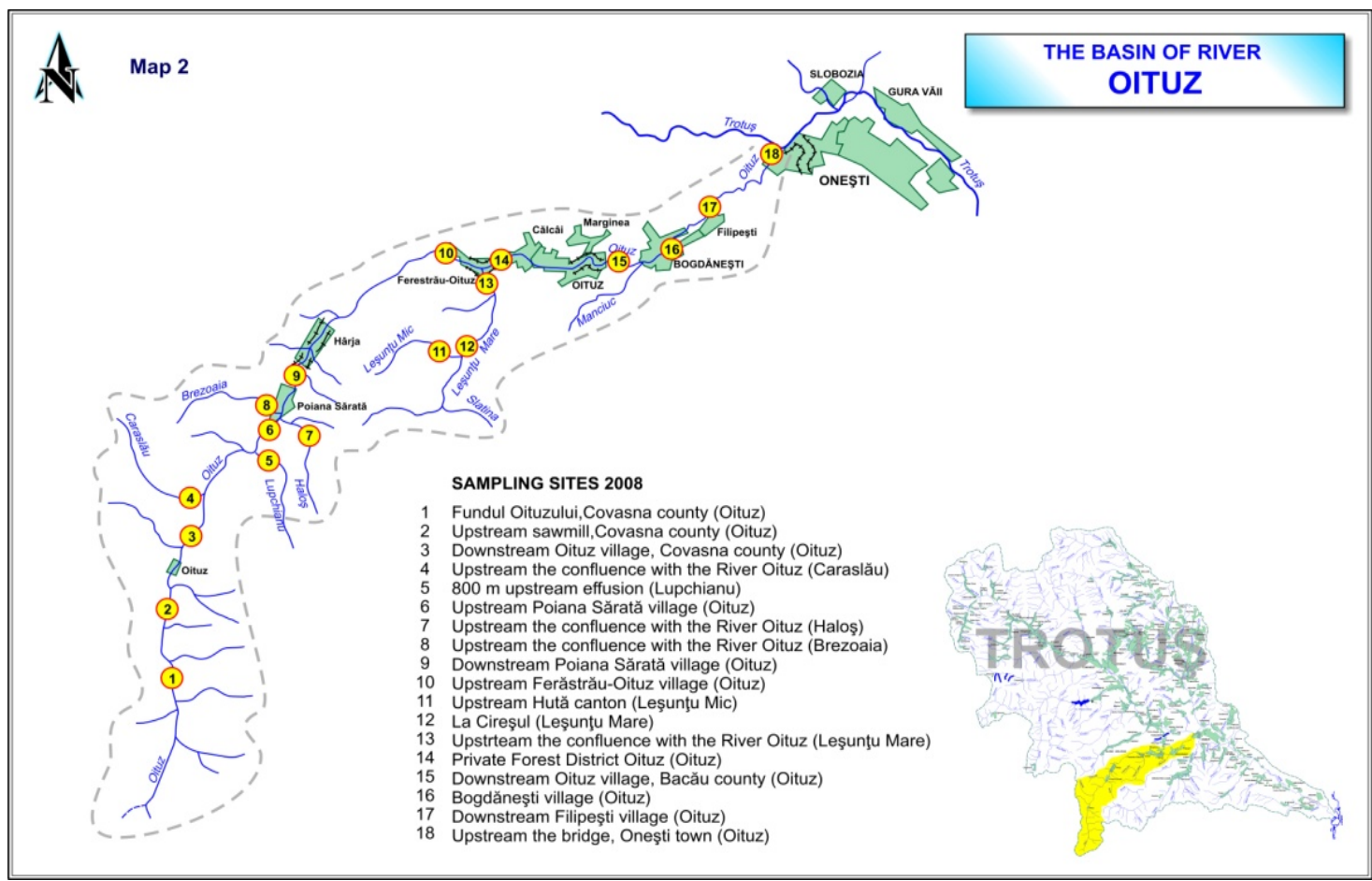

Figure 2: Sampling sites used in 2008 in the basin of river Oituz.

For the other species, the optimum conditions are defined by: $\mathrm{pH}$ 7-7.5 and temperature between two and 20 degrees Celsius for Phoxinus phoxinus; pH 6-7.8 and 4-20 degrees Celsius for Squalius cephalus; 5-25 degrees Celsius for Barbus meridionalis (Froese and Pauly, 2014). 


\section{RESULTS AND DISCUSSION}

Related to 2008, in the case of Phoxinus phoxinus species, we have obtained a model which covers $87 \%$ of the measured data (Fig. 3) for the fish length and about $80 \%$ of the collected data in the case of fish weight (Fig. 4) The equations which describe the multiple regression models are given below:

$$
\begin{gathered}
L_{\text {med }}=68.0473-3.2472 \cdot T-6.3250 \cdot P h+0.3284 \cdot T \cdot P h \\
R^{2}=0.87, \quad p=0.005 \\
G_{\text {med }}=88.0833-4.7570 \cdot T-8.5523 \cdot P h+0.4810 \cdot T \cdot P h \\
R^{2}=0.8059, \quad p=0.003
\end{gathered}
$$

In statistics, it is well known that the greater the slope (or regression coefficient) the more influence the independent variable has on the dependent variable; if the regression coefficient is negative, the variables are negatively correlated, (one variable increases and the other one decreases).

For $L_{\text {med }}$ and $G_{\text {med }}$, the coefficient of the above regressions are negative, which involves a negative dependence of the dependent variables on the considered predictors.

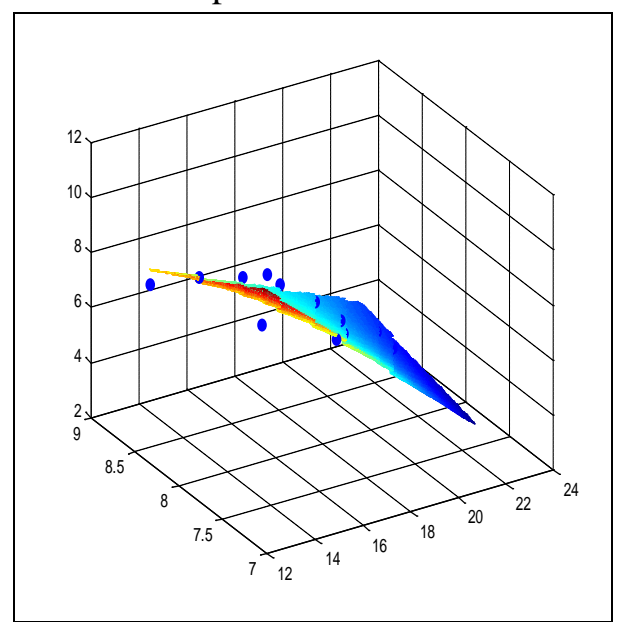

Figure 3: Length, temperature and pH correlation for Phoxinus phoxinus.

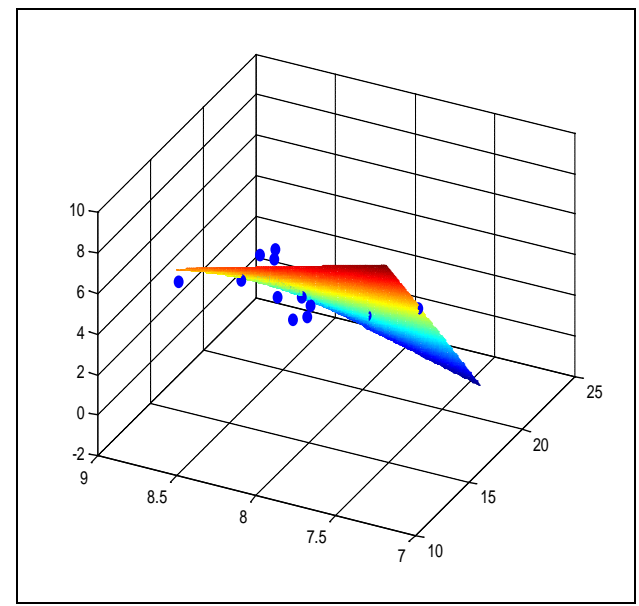

Figure 4: Weight, temperature and $\mathrm{pH}$ correlation for Phoxinus phoxinus. 
For Salmo trutta fario species, taking into account the same variables of the model, we have obtained the following results for 2008:

- $\quad$ for length, the statistical model covers $87 \%$ from the collected data (Fig. 5)

$$
\begin{gathered}
L_{\text {med }}=919.69-21.7525 \cdot T-104.6385 \cdot P h+0.3284 \cdot T \cdot P h^{3}, \\
R^{2}=0.8735, \quad p=0.0016
\end{gathered}
$$

- $\quad$ for weight, the statistical model covers $76 \%$ from the collected data (Fig. 6 )

$G_{\text {med }}=5489.9-131.8 \cdot T-626.8 \cdot P h+0.2 \cdot T \cdot P h^{3}$

$$
R^{2}=0.7651, \quad p=0.01
$$

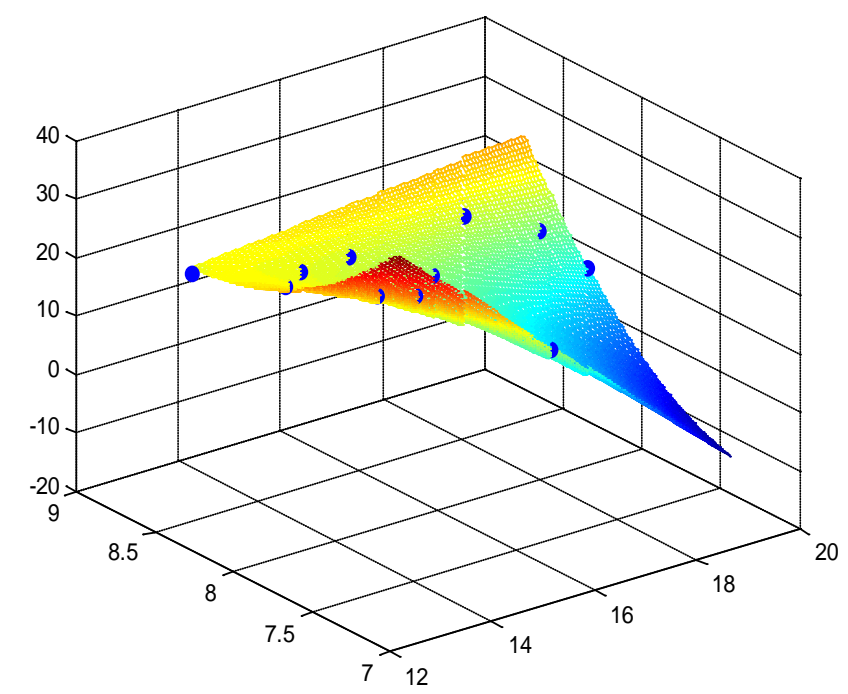

Figure 5: Length, temperature and pH correlation for Salmo trutta fario.

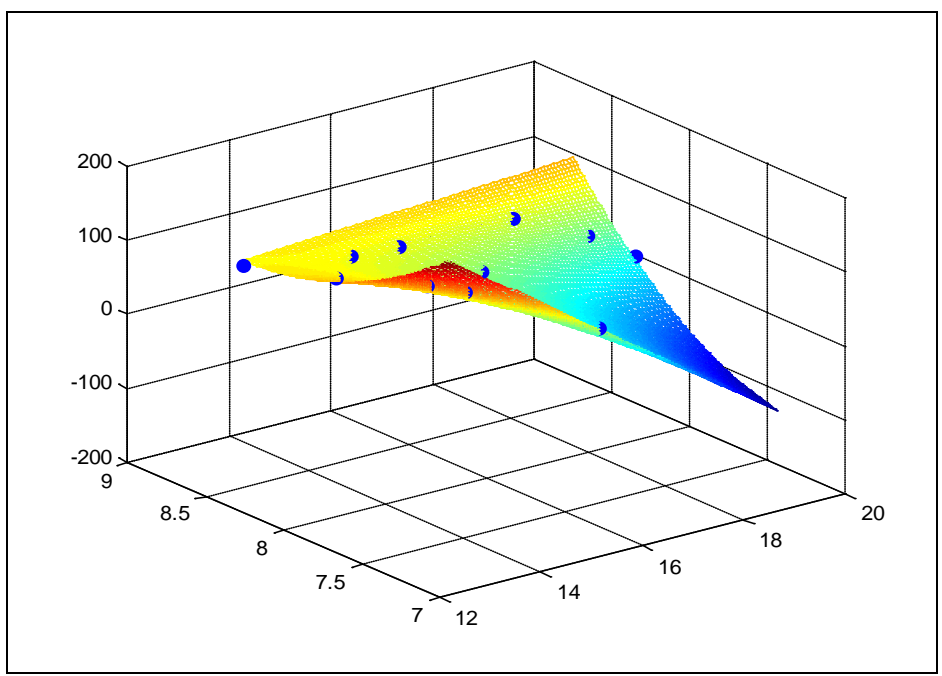

Figure 6: Weight, temperature and $\mathrm{pH}$ correlation for Salmo trutta fario. 
The following analysis reveals a species that is not very sensible at the variation of the water temperature and $\mathrm{pH}$. Barbus meridionalis species has a relatively high prevalence in Romania; it manifests a process of territorial expansion and is considered as having low vulnerability.

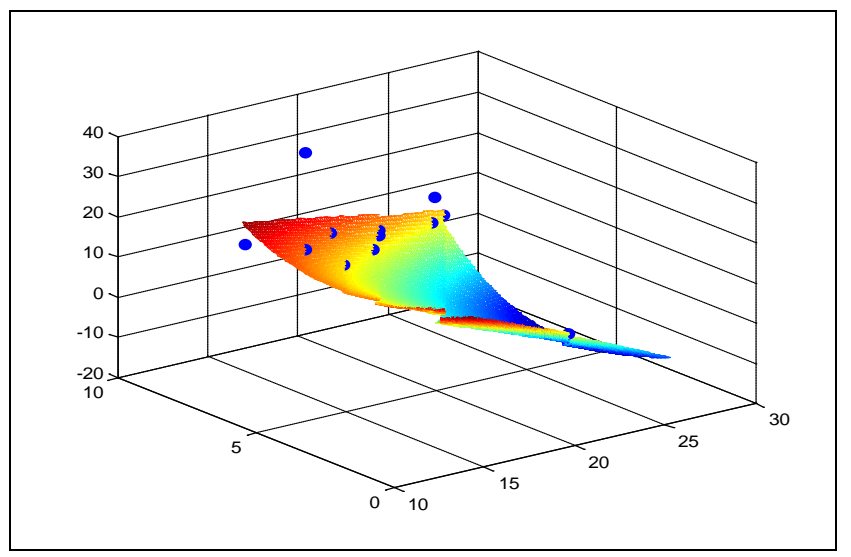

Figure 7: Length, temperature and $\mathrm{pH}$ correlation for Barbus meridionalis.

We noticed (Fig. 7) that the estimation model covers only 25\% of the collected data for the weight as dependent variable and about $23 \%$ for the length as dependent variable.

In the case of Squalius cephalus species:

- for the dependent variable length, the statistical model covers $72 \%$ of the collected data (Fig. 8)

$$
\begin{gathered}
L_{\text {med }}=-1196.3+53.3 \cdot T+143.4 \cdot P h-0.6 \cdot T \cdot P h, \\
R^{2}=0.7269, \quad p=0.07
\end{gathered}
$$

- for the dependent variable weight, the statistical model covers $95 \%$ of the collected data (Fig. 9)

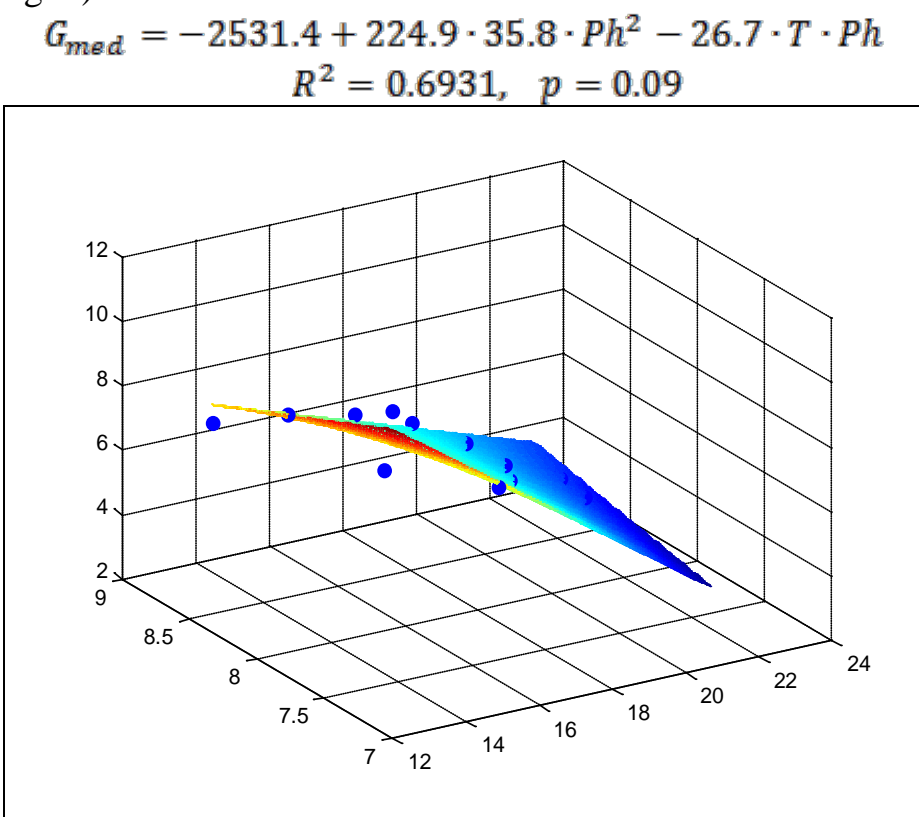

Figure 8: Length, temperature and pH correlation for Squalius cephalus. 


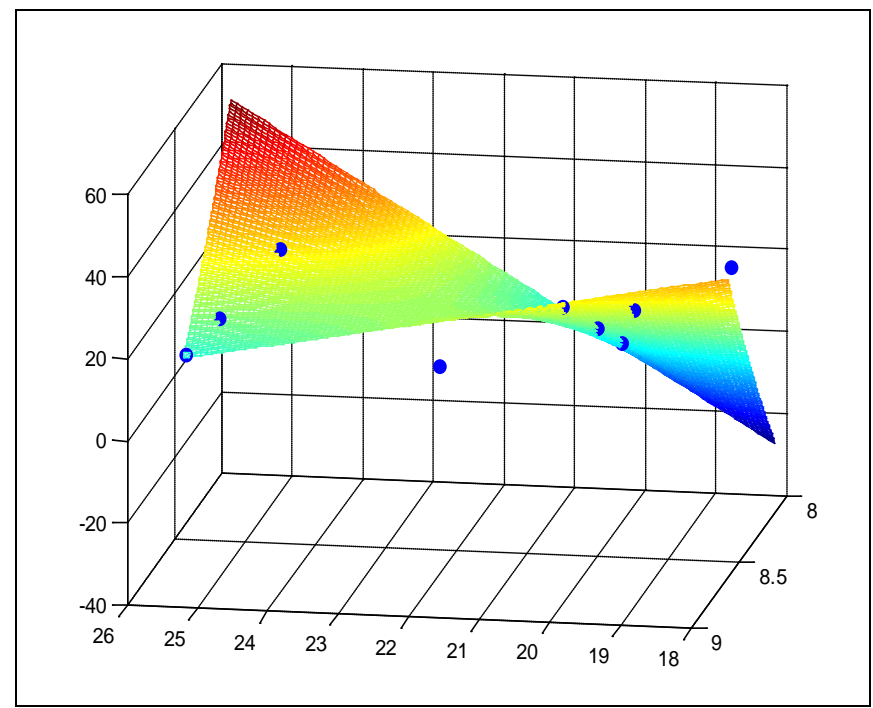

Figure 9: Weight, temperature and pH correlation for Squalius cephalus.

For the year 2004, the same analysis has been performed for the considered species and the estimated models are slightly different from those for 2008.
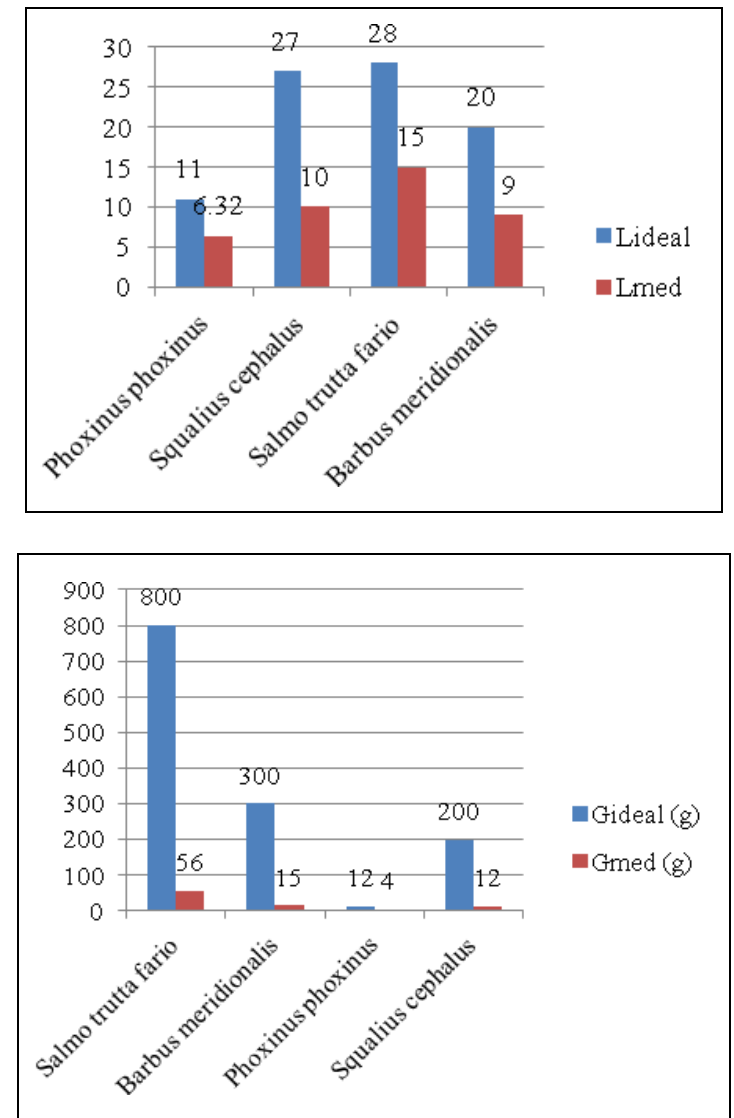

Figure 10: The ideal values of fish length and weight versus the real values. 


\section{CONCLUSIONS}

For the considered species, the statistical analysis on the available data reveals that there are several species of fish that are more sensitive to the environmental changes, while others are not. In the case of Salmo trutta fario, the rate of growth varies widely, depending on the thermal and trophic conditions. For most of the species in our study (except for Squalius cephalus) because they are cold water fish, both length and weight increase at low temperatures. A major reason for the change in $\mathrm{pH}$, which can greatly affect the fish metabolism, is given by the presence of houses in the area. Squalius cephalus species grows better in environments with temperatures which are not typical for a mountain water (see the positive coefficients of water temperature and $\mathrm{pH}$ ). Because there are no major sources of industrial pollution, the water quality in Oituz River basin has normal parameters, so the ichthyofauna is not significantly affected. For the considered species we can conclude that Squalius cephalus and Barbus meridionalis species are more adaptable to the climate and environmental changes than the other two species (Phoxinus phoxinus and Salmo trutta fario).

However, the data analysis reveals that the individuals do not reach maturity, either due to the domestic pollution caused by the towns bordering the river, or due to the anthropic influence (such as overfishing) (Fig. 10).

\section{ACKNOWLEDGEMENTS}

This research was financially supported by the Romanian Executive Unit for Financing Higher Education, Research, Development and Innovation (Grant PN-II-PT-PCCA-2011-3.2-1108, "Networked interactive ceramic whiteboards with integrated sound (ENO) for teaching and learning science and technology"). 


\section{REFERENCES}

1. Balddisserotto B., 2011 - Water $\mathrm{pH}$ and hardness affect growth of freshwater teleosts, Revista Brasileira de Zootecnia, 40, (supl. especial), 138-144.

2. Bănărescu P., 1964 - Pisces - Osteichthyes, Edit. Academiei Republicii Populare Române, București, 959. (in Romanian)

3. Berkes F., 2007 - Understanding Uncertainty and Reducing Vulnerability: Lessons from Resilience Thinking, Natural Hazards, 41, 283-295.

4. Bousquet F. and Le Page C., 2004 - Multi-Agent Simulations and Ecosystem Management: a review, Ecological Modelling, 176, 313-332.

5. Carpenter S., Brock W. and Hanson P. 1999 - Ecological and social dynamics in simple models of ecosystem management, Conservation Ecology, 3, 2, 4. (online) URL: http://www.consecol.org/vol3/iss2/art4/

6. $\quad$ Froese R. and Pauly D. (eds), 2014 - FishBase, http://www.fishbase.org, 24 May 2014.

7. Fulton E. A., Smith A. D. M., Smith D. C. and Van Putten I. E., 2011 - Human Behaviour: The Key Source of Uncertainty in Fisheries Management, Fish and Fisheries, 12, 1, 2-17.

8. Hilborn R. and Walters C. J., 1987 - A General Model for Simulation of Stock and Fleet Dynamics in Fisheries, Canadian Journal of Fisheries and Aquatic Sciences, 44, 1366-1370.

9. Ibarra A. A., Park Y. S., Brosse S., Reyjol Y., Lim P. and Lek S., 2005 - Nested patterns of spatial diversity revealed for fish assemblages in a west European river, Ecology of Freshwater Fish, 14, 233-242.

10. Milner-Gulland E. J., 2011 - Integrating Fisheries Approaches and Household Utility Models for Improved Resource Management, Proceedings of the National Academy of Sciences of the United States of America, 108, 4, 1741-1746.

11. Moyle P. B., 2002 - Inland Fishes of California, Revised and expanded, University of California Press, 489.

12. Nathans, L. L., Oswald, F. L., Nimon, K., 2012 - Interpreting multiple regression: A guidebook of variable importance, Practical Assessment, Research and Evaluation, 9, 1-19.

13. North E. W., Gallego A. and Petitgas P., 2009 - Looking to the future: recommendations and research needs, in Manual of Recommended Practices for Modelling Physical - Biological Interactions during Fish Early Life, 83-107, North E. W., Gallego A. and Petitgas P., (eds), ICES Cooperative Research Report no. 295, 112.

14. Raleigh R. F., Zuckerman L. D. and Nelson P. C., 1986 - Habitat suitability index models and instream flow suitability curves: Brown trout, revised, U.S. Fish and Wildlife Service Biological Report, 82, 65.

15. Schlüter M., McAllister R. R. J., Arlinghaus R., Bunnefeld N., Eisenack K., Hölker F., MilnerGulland E. J., Müller B., Nicholson E., Quaas M. and Stöven M., 2012 - New horizons for managing the environment: A review of coupled social-ecological systems modeling, Natural Resource Modeling, 25, 1, 219-292.

16. Schmolke A., Thorbek P., De Angelis D. L. and Grimm V., 2010 - Ecological Models Supporting Environmental Decision Making: A Strategy for the Future, Trends in Ecology and Evolution, 25, 8, 479-486.

17. Simon T. P., 1999 - Biological Integrity and Use of Ecological Health Concepts for Application to Water Resource Characterization, in Simon T. P. (ed.), Assessing the Sustainability and Biological Integrity of Water Resources Using Fish Communities, CRC Press LLC, Boca Raton, Florida, 3-16.

18. Ujváry I., 1972 - Geografia apelor României, Edit. Științifică, București, 590.

19. Wetzel, R. G. 2001 - Limnology: Lake and River Ecosystems (3rd edition), San Diego, CA, Academic Press, 1006.

20. ***, 1992 - Atlasul cadastrului apelor din Romania, 555. (in Romanian) 